\title{
"O SUPORTE INFORMACIONAL DA CONTROLADORIA PARA O PROCESSO DECISÓRIO DA DISTRIBUIÇÃO FÍSICA DE PRODUTOS”
}

\author{
Verônica de Miglio Moura \\ Professora do Centro de Educação Superior - ÚNICA \\ Professora da Universidade do Vale do Itajaí - UNIVALI \\ vmiglio@uol.com.br \\ Ilse Maria Beuren \\ Professora Doutora da Universidade Federal de Santa Catarina \\ beuren@cse.ufsc.br
}

ABSTRACT

O objetivo da pesquisa, a partir da qual foi elaborado este artigo, consiste em averiguar o suporte informacional da Controladoria para o processo decisório da Logística, com vistas à função de distribuição física dos produtos. Neste sentido, selecionou-se três empresas, a partir de uma relação das empresas de capital aberto do estado de Santa Catarina, obtida junto à homepage da Comissão de Valores Mobiliários - CVM, que possuem uma Controladoria enquanto órgão administrativo e um setor de Logística. Constatou-se que a Controladoria exerce suas funções a fim de contribuir para a otimização dos resultados globais da empresa, contudo não necessariamente gerencia o sistema de informações contábeis-gerenciais nas mesmas. Portanto, conclui-se que os relatórios contábeisgerenciais gerados pela Controladoria com vistas à função da distribuição física de produtos, em geral, não são emitidos de forma específica para o processo decisório da Logística, visto que esta particularidade somente ocorre a partir do momento em que a Controladoria gerencia o sistema de informações. Nas empresas pesquisadas esta função é atribuída à Controladoria em apenas uma delas.

Palavras-chave: controladoria, logística, processo decisório.
The research that underlies this article aimed to examine the informational support provided by Controllership to the Logistics' decision-making process, with a view to the physical product distribution function. Thus, three companies were selected from a list of publicly traded companies from Santa Catarina State, which possess a Controller's department as an administrative organ, as well as a Logistics sector. This list was obtained from the homepage of the Comissão de Valores Mobiliários - CVM. It was disclosed that the Controller's department exerts its functions in order to contribute to the optimization of the company's global results, although it does not necessarily manage the company's management accounting information system. Therefore, it was concluded that the management accounting reports, generated by the Controller's Department with a view to the physical product distribution function, generally are not issued in a specific way for the Logistics' decision-making process, since this particularity only occurs when the Controller's department manages the information system. In the companies that were examined, this function is attributed to the Controller's department in only one case.

Keywords: Controller's department, logistics, decision-making process 


\section{INTRODUÇÃO}

O atual contexto econômico e social é caracterizado por um elevado grau de competição entre as empresas, decorrente, principalmente, do uso intensivo de tecnologia de informação, bem como da abertura do mercado para novos participantes e produtos.

Dentro deste contexto globalizado, as empresas passam a ter novas preocupações. Christopher ${ }^{1}$ menciona que, uma vez que os produtos são padronizados, "os clientes vêem pouca diferença entre as características físicas ou funcionais dos produtos", dessa forma, passa a ser por meio dos serviços que cada organização mostra a sua diferença.

Diante de um novo cenário econômico e social, que alterou fatores como concorrência, exigências do cliente, critérios de qualidade, atendimento e demais serviços, ocorreu, então, o surgimento e evolução de novos conceitos que proporcionem vantagem competitiva no atendimento ao cliente, dentre eles a logística, assumindo não só um caráter operacional, mas também estratégico. As empresas passaram, com isso, a ajustar suas táticas de logística continuamente, propiciando, assim, uma capacidade de reação às constantes mudanças do ambiente.

Para Pereira e Fonseca ${ }^{2}$, "a sobrevivência das empresas no mundo globalizado depende da velocidade de assimilação das informações e da correspondente agilidade decisória nesse contexto". Desse modo, torna-se essencial ao processo decisório o suporte informacional. Diante do exposto, verifica-se que é ponto fundamental o acesso às informações de forma sinérgica e eficaz para que as empresas ajustem suas táticas de logística.

Assim, faz-se necessário confirmar o papel da Controladoria de dar suporte informacional ao planejamento, controle e proteção dos interesses da empresa. Deve-se ressaltar que o gerenciamento do sistema de informação pela Controladoria não será substituto de uma gestão eficaz, nem será capaz de corrigir os erros de uma gestão ineficiente. Contudo, a Controladoria exerce forte influência sobre a administração, rumo a decisões lógicas e compatíveis com os objetivos da organização, ou seja, ela possui a função de fazer com que os recursos disponíveis sejam aplicados para a otimização dos resultados da empresa.

Nesta perspectiva, buscou-se verificar o suporte informacional da Controladoria para o processo decisório da Logística, com vistas à função de distribuição física de produtos em empresas que possuem estes dois órgãos em sua estrutura formal.

\section{GESTÃO DA LOGÍSTICA}

O campo da logística surgiu desde o momento em que o homem primitivo produziu no próprio local mais do que poderia consumir. Como conseqüência deste excesso de produtos surgiu a necessidade de transportá-los a outros locais. Diante desta necessidade, as conquistas tecnológicas na área da produção tinham que encontrar uma solução adequada para a distribuição física, promoção de vendas e para o suprimento de produtos.

Segundo Novaes $^{3}$, a logística preocupa-se em "agregar valor de lugar, de tempo, de qualidade e de informação à cadeia produtiva". O valor de lugar é criado pelo transporte, enquanto que o valor de tempo é criado pela disponibilidade do produto ou serviço, no momento do consumo. O valor de qualidade é considerado em relação à qualidade da operação logística, que corresponde à entrega do produto certo, na hora certa, em perfeitas condições e ao preço justo. $O$ valor de informação diz respeito à possibilidade que existe hoje de, por exemplo, rastrear a carga enquanto está sendo transportada.

Diante da preocupação da logística em agregar valor à cadeia produtiva, Christopher ${ }^{4}$ explica que "o serviço ao cliente pode ser definido como um fornecimento consistente das utilidades de tempo e lugar",

${ }^{1}$ CHRISTOPHER, Martin. Logística e gerenciamento da cadeia de suprimentos: estratégias para a redução de custos e melhoria dos serviços. São Paulo: Pioneira, 1997. ${ }^{2}$ PEREIRA, Maria José Lara de Bretas; FONSECA, João Gabriel Marques. Faces da decisão: as mudanças de paradigmas e o poder da decisão. São Paulo: Makron Books, 1997, p.240.

${ }^{3}$ NOVAES, Antônio Galvão. Logística e gerenciamento da cadeia de distribuição: estratégia, operação e avaliação. Rio de Janeiro: Campus, 2001 , p.35.

${ }^{4}$ CHRISTOPHER, Martin. Logística e gerenciamento da cadeia de suprimentos: estratégias para a redução de custos e melhoria dos serviços. São Paulo: Pioneira, 1997 , p.17. 
ou seja, o produto somente terá valor se for entregue ao consumidor final na hora e local exigidos. Dessa forma, complementa, "o papel do serviço ao cliente deve ser a melhoria do valor de uso, significando, com isso, que o produto passa a ter mais valor aos olhos do cliente, porque o serviço adicionou valor à essência do produto", sendo assim, um diferencial competitivo para as organizações.

Neste sentido, a logística foi reconhecida como fator relevante na vida econômica e social das empresas. Isto porque antes se considerava que a circulação de mercadorias era apenas conseqüência das decisões sobre organização do espaço: criavam-se as infra-estruturas de transportes para interligar as zonas de produção e de consumo. Somente mais tarde é que se passou a ter consciência da necessidade da integração do problema de transportes de mercadorias, seja em nível nacional ou internacional, visando atender às necessidades do consumidor final, o cliente.

Segundo Bowersox e Closs ${ }^{5}$, os gastos com logística por parte das empresas "variam normalmente de 5 a $35 \%$ do valor das vendas, dependendo do tipo de atividade, da área geográfica de operação e da relação peso/valor dos produtos e materiais". Neste sentido, a logística se apresenta como responsável por uma das maiores parcelas do custo final do produto, sendo superada apenas pelos materiais consumidos na produção ou pelo custo dos produtos vendidos no atacado ou no varejo.

Diante do exposto, verifica-se ser a logística uma atividade de caráter estratégico, mas também de alto custo. Torna-se necessário, então, entender o que é a logística, bem como o conceito de gerenciamento da cadeia de suprimento, visto que este conceito engloba a integração das atividades pertinentes à logística, para, então, compreender a gestão da distribuição física de produtos, uma vez que somente conhecendo tais conceitos, poder-se-á compreender os aspectos relevantes da logística como fator de vantagem competitiva nas organizações.

\subsection{Evolução do conceito de logística}

De acordo com Rodrigues ${ }^{6}$, "a primeira tentativa de definir logística foi feita pelo Barão Antoine Henri de Jomini (1779/1869), General do exército francês sob o comando de Napoleão Bonaparte, que em seu Compêndio da Arte da Guerra, a ela se referiu como a arte prática de movimentar exércitos". Complementa citando que o termo logistique é "derivado de um posto existente no exército francês durante o século XVII Marechal des Logis", o soldado que ocupasse tal posto era o responsável pelas atividades administrativas relativas ao deslocamento, alojamento e acampamento das tropas em campanha.

Durante a II Guerra Mundial, a logística adquiriu uma amplitude maior, em virtude das operações militares realizadas. Rodrigues ${ }^{7}$ afirma que "as Forças Armadas aliadas compreenderam que logística abrangia todas as atividades relativas à provisão e administração de materiais, pessoal e instalações, além da obtenção e prestação de serviços de apoio".

No inicio da década de noventa, Chiavenato ${ }^{8}$ cita que a logística era conceituada como a "atividade que coordena a estocagem, o transporte, os armazéns, os inventários e toda a movimentação dos materiais dentro da fábrica até a entrega dos produtos acabados ao cliente".

Por sua vez, em meados da mesma década, surge o termo logística empresarial, que para Ballou ${ }^{9}$ "trata de todas as atividades de movimentação e armazenagem, que facilitam o fluxo de produtos desde o ponto de aquisição da matéria-prima até o ponto de consumo final, assim como dos fluxos informativos que colocam os produtos em movimento, com o propósito de providenciar níveis de serviço adequados aos clientes a um custo razoável". Nota-se que a partir deste conceito a cadeia produtiva passa a englobar a aquisição da matéria-prima, ou seja, o suprimento de materiais, passando a cadeia a ser considerada de forma mais ampla.

${ }^{5}$ BOWERSOX, Donald J; CLOSS, David J. Logística empresarial: o processo de integração da cadeia de suprimento. São Paulo: Atlas, 2001 , p.20.

${ }^{6}$ RODRIGUES, Paulo Roberto Ambrosio. Introdução aos sistemas de transporte no Brasil e à logística internacional. São Paulo: Aduaneiras, 2000, p.95.

${ }^{7}$ Idem. P.95.

${ }^{8}$ CHIAVENATO, Idalberto. Iniciação à administração de materiais. São Paulo: Makron Books, 1991, p.37.

${ }^{9}$ BALLOU, Ronald H. Logística empresarial: transportes, administração de materiais e distribuição física. São Paulo: Atlas, 1993, p. 24 
Sob esta ótica, Christopher ${ }^{10}$ define logística como o "processo de gerenciar estrategicamente a aquisição, movimentação e armazenagem de materiais, peças e produtos acabados (e os fluxos de informações correlatas) através da organização e seus canais de marketing, de modo a poder maximizar as lucratividades presente e futura através do atendimento dos pedidos a baixo custo". Aqui o diferencial passa a ser a estratégia, associada ao gerenciamento da cadeia produtiva.

No final da década de noventa, apresenta-se, então, um conceito mais abrangente, no qual a logística, conforme Ching ${ }^{11}$, pode ser entendida como o "gerenciamento do fluxo logístico de materiais que começa com a fonte de fornecimento no ponto de consumo. É mais do que uma simples preocupação com produtos acabados, o que era a tradicional distribuição física. Na realidade, a logística está preocupada com a fábrica e os locais de estocagem, níveis de estoques e sistemas de informações, bem como com seu transporte e armazenagem". Percebe-se que, neste momento, o atendimento às necessidades do cliente passa a ser o referencial para o gerenciamento da cadeia.

Mais recentemente, Novaes ${ }^{12}$ cita que a logística incorpora prazos previamente definidos (e cumpridos); preços transparentes para o cliente; satisfação plena do cliente (nível de serviço); integração efetiva e sistêmica entre todos os setores da empresa; integração efetiva com fornecedores e clientes (supply chain); e busca da otimização global (redução global dos custos), incluindo estoques, transporte, avarias, perdas etc.

Diante do exposto, verifica-se que a logística hoje incorpora o conceito de Supply Chain Management, que corresponde a uma integração da cadeia desde o suprimento até o abastecimento, tendo como pontos fundamentais o nível de serviço ao cliente, ou seja, o atendimento das necessidades do mesmo, bem como a redução de custos, sem que haja perda da qualidade do produto ou do serviço.

O Council of Logistics Management - CLM, no encontro internacional que foi promovido em Toronto/Canadá, em outubro de 1999, definiu logística como "a parte do processo da cadeia de suprimento que planeja, implementa e controla o eficiente e efetivo fluxo de estocagem de bens, serviços e informações relacionadas, do ponto de origem ao ponto de consumo, visando atender aos requisitos dos consumidores." 13

Bowersox e Closs ${ }^{14}$ explicitam que "o gerenciamento logístico inclui o projeto e a administração de sistemas para controlar o fluxo de materiais, os estoques em processos e os produtos acabados, com o objetivo de fortalecer a estratégia das unidades de negociações da empresa".

É importante ressaltar que o gerenciamento logístico assume caráter estratégico nas empresas por provocar o aumento da lucratividade para as mesmas. Kotler ${ }^{15}$ afirma que tal deve-se ao fato de a logística de mercado envolver "o planejamento, a implementação e o controle dos fluxos físicos de materiais e de produtos finais entre os pontos de origem e os pontos de uso, com o objetivo de atender às exigências dos clientes e de lucrar com esse atendimento".

Percebe-se que o conceito de logística passou por algumas mudanças, porém é ponto comum entre os autores que a logística empresarial engloba o suprimento físico e a distribuição física de produtos. Neste sentido, a função logística nas organizações, atualmente, deve estar alicerçada no conceito de Supply Chain Management para nortear seu processo decisório.

\footnotetext{
${ }^{10}$ CHRISTOPHER, Martin. Logística e gerenciamento da cadeia de suprimentos: estratégias para a redução de custos e melhoria dos serviços. São Paulo: Pioneira, 1997, p.2.

${ }^{11}$ CHING, Hong Yuh. Gestão de estoques na cadeia de logística integrada: supply chain. São Paulo: Atlas, 1999, p.17.

${ }^{12}$ NOVAES, Antônio Galvão. Logística e gerenciamento da cadeia de distribuição: estratégia, operação e avaliação. Rio de Janeiro: Campus, 2001, p.37.

${ }^{13}$ COUNCIL OF LOGISTICS MANAGEMENT - CLM. Definição de logística dada pelo CLM. Disponível em: <http://www.clm1.org/index.asp>. Acessado em: 31 de janeiro 2001.

${ }^{14}$ BOWERSOX, Donald J; CLOSS, David J. Logística empresarial: o processo de integração da cadeia de suprimento. São Paulo: Atlas, 2001, p.21.

${ }^{15}$ KOTLER, Philip. Administração de marketing: a edição do novo milênio. 11.ed. São Paulo: Prentice Hall, 2001, p. 558.
} 


\subsection{Supply Chain Management}

Em 1963 foi fundado nos Estados Unidos o Conselho Nacional de Gerenciamento da Distribuição Física, no qual seus participantes descobriram algumas interfaces entre as funções de armazenagem e transporte, passando a integrá-las no gerenciamento da distribuição física.

Logo em seguida, constataram que o atendimento aos pedidos reduzia-se consideravelmente, trazendo como benefício imediato a redução dos estoques pela confiabilidade na freqüência do transporte, otimizando a taxa de ocupação dos armazéns e melhorando o nível dos serviços.

Christopher ${ }^{16}$ explicita que "o gerenciamento logístico exige que todas as atividades que ligam o mercado fornecedor ao mercado consumidor sejam vistas como um sistema interligado - tendo, como problema principal, o fato que o impacto de uma decisão tomada em qualquer parte do sistema afetará o sistema inteiro", o que demonstra a integração do sistema logístico.

Segundo o Fórum de Supply Chain Management
(SCM), realizado na Ohio State University, Supply Chain Management ou Gerenciamento da Cadeia de Suprimento foi definido como sendo "a integração dos processos industriais e comerciais partindo do consumidor final e indo até os fornecedores iniciais, gerando produtos, serviços e informações que agreguem valor para o cliente." ${ }^{17}$.

O conceito de Supply Chain envolve não só os atores internos da corporação, mas também os fornecedores e clientes, ampliando a cadeia de valor da companhia. A partir do momento em que se amplia o escopo do relacionamento logístico para além das fronteiras da companhia, mais recursos e maior sofisticação gerencial é requerida, a fim de existir uma vantagem competitiva na empresa.

A Figura 1 representa a integração da cadeia de suprimento, conforme o conceito de SCM, que consiste na integração externa com fornecedores e clientes, quando se obtém relacionamentos de parcerias externas que envolvem compartilhamento de informações e ações, diferentemente dos sistemas convencionais, criando uma dependência complexa entre as partes da cadeia.

\section{Figura 1 - Supply Chain Management}

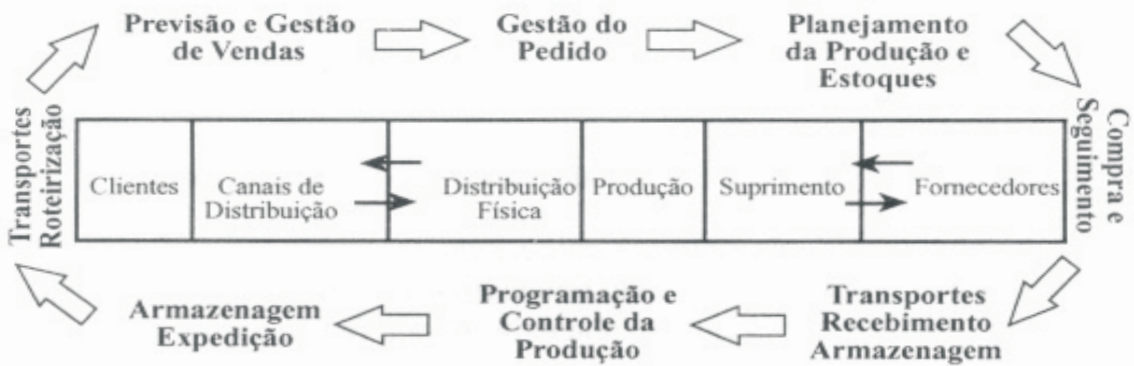

FONTE: RODRIGUES, Paulo Roberto Ambrosio. Introdução aos sistemas de transporte no Brasil e à logística internacional. São Paulo: Aduaneiras, 2000, p.109.

Verifica-se a completa interligação entre as diversas atividades da cadeia, como o suprimento, o planejamento e controle da produção e dos estoques, bem como o transporte das mercadorias até o cliente.

Christopher ${ }^{18}$ menciona que para as empresas de hoje alcançarem, no futuro, uma posição de van- tagem competitiva contínua, deverão ter "integradores orientados para a obtenção de sucesso no mercado, baseado em sistemas de gerenciamento de operações e entregas". Portanto, a logística passa a ser, dentro de uma visão integrada de todo o processo e de todos os participantes da cadeia, um diferencial que traz vantagem competitiva às empresas.

${ }^{16}$ CHRISTOPHER, Martin. Logística e gerenciamento da cadeia de suprimentos: estratégias para a redução de custos e melhoria dos serviços. São Paulo: Pioneira, 1997 , p.25. ${ }^{17}$ NOVAES, Antônio Galvão. Logística e gerenciamento da cadeia de distribuição: estratégia, operação e avaliação. Rio de Janeiro: Campus, 2001 , p.41.

${ }^{18}$ CHRISTOPHER, Martin. Logística e gerenciamento da cadeia de suprimentos: estratégias para a redução de custos e melhoria dos serviços. São Paulo: Pioneira, 1997, p.21. 
Diante do exposto, os objetivos do Gerenciamento da Cadeia de Suprimentos, conforme explicitado por Slack et al. ${ }^{19}$, são: (1) focalizar na satisfação dos clientes finais; (2) formular e implementar estratégias baseadas na obtenção e retenção de clientes finais; e (3) gerenciar a cadeia de maneira eficaz e eficiente.

Neste sentido, torna-se relevante aprender como obter a satisfação do cliente e atingir tal satisfação, por meio do gerenciamento eficaz e eficiente da cadeia, especificamente a gestão da distribuição física de produtos.

\subsection{Nível de serviço logístico}

Para $\mathrm{Magee}^{20}$, o sistema de distribuição física deve ser pensado "sobre as características e necessidades ou interesses dos clientes da empresa (ou dos consumidores finais)". Tal conduz ao objetivo central da logística, que corresponde a oferecer 0 maior nível de serviço ao cliente, atendendo às utilidades de tempo e lugar.

O nível de serviço logístico ao cliente é definido por Ballou ${ }^{21}$ como:

"a qualidade com que o fluxo de bens e serviços é gerenciado. É o resultado líquido de todos os esforços logísticos da firma. É o desempenho oferecido pelos fornecedores aos seus clientes no atendimento dos pedidos. $O$ nível de serviço logístico é fator-chave do conjunto de valores logísticos que as empresas oferecem a seus clientes para assegurar sua fidelidade. Como o nível de serviço logístico está associado aos custos de prover esse serviço, o planejamento da movimentação de bens e serviços deve iniciar-se com as necessidades de desempenho dos clientes no atendimento de seus pedidos."

Diante do exposto, pode-se observar que um novo paradigma passou a ser adotado pelas empresas. Estas precisam saber o que o cliente deseja para que possa satisfazê-lo, obtendo lucro, ou seja, administrando seus custos e receitas.

Ching ${ }^{22}$ comenta que "os clientes exigem cada vez maiores níveis de serviço" o que inclui a "rápida entrega com curto espaço de tempo de notificação pelo cliente, reposição contínua de mercadoria, entregas para os pontos de uso (...), capacidade de transação via EDI, transmissão eletrônica de dados".

O serviço logístico, de acordo com Bowersox e Closs $^{23}$, "é medido em termos de (1) disponibilidade; (2) desempenho operacional; e (3) confiabilidade de serviço". A disponibilidade diz respeito ao estoque mantido pela empresa, o que não significa dizer que a mesma deve manter níveis elevados de estoque, ou estoque zero, e sim que deve gerenciá-los de maneira eficiente e eficaz a fim de evitar a falta do produto (ou o excesso do mesmo), bem como existem diversas ferramentas gerenciais que podem ser utilizadas para tal.

O desempenho operacional refere-se ao intervalo de tempo entre o recebimento do pedido e a entrega da respectiva mercadoria. O desempenho operacional está relacionado à velocidade e consistência da entrega, contudo uma entrega rápida não é sinônimo de um eficiente e eficaz desempenho operacional, pois deve-se atentar para a regularidade da entrega. Além disso, relaciona-se a flexibilidade no atendimento de pedidos inesperados, bem como o atendimento ao cliente após a entrega realizada (pós-venda).

A confiabilidade de serviço relaciona-se à qualidade do serviço logístico, que consiste na mensuração precisa da disponibilidade e do desempenho operacional, ou seja, depende do equilíbrio entre a disponibilidade eficiente do estoque e um bom nível de desempenho operacional.

Christopher ${ }^{24}$ explica que o serviço ao cliente pode ser examinado sob três dimensões: elementos de pré-transação; da transação; e da pós-transação. Como exemplo de elementos da pré-transação, pode-se citar a política formal de serviço ao

${ }^{19}$ SLACK, Nigel et al. Administração da produção. São Paulo: Atlas, 1997, p.426-427.

${ }^{20}$ MAGEE, John F. Logística industrial: análise e administração dos sistemas de suprimento e distribuição. São Paulo: Pioneira, 1977 , p.318.

${ }^{21}$ BALLOU, Ronald H. Logística empresarial: transportes, administração de materiais e distribuição física. São Paulo: Atlas, 1993 , p. 73.

${ }^{22} \mathrm{CHING}$, Hong Yuh. Gestão de estoques na cadeia de logística integrada: supply chain. São Paulo: Atlas, 1999 , p.147.

${ }^{23}$ BOWERSOX, Donald J; CLOSS, David J. Logística empresarial: o processo de integração da cadeia de suprimento. São Paulo: Atlas, 2001 , p.24.

${ }^{24}$ CHRISTOPHER, Martin. Logística e gerenciamento da cadeia de suprimentos: estratégias para a redução de custos e melhoria dos serviços. São Paulo: Pioneira, 1997 , p.29-31. 
cliente, a acessibilidade, a estrutura organizacional e a flexibilidade do sistema.

São exemplos de elementos da transação, o ciclo do pedido, a disponibilidade de estoque, a taxa de cumprimento do pedido e informações sobre a posição do pedido. Por último, exemplificando os elementos da pós-transação tem-se a disponibilidade de peças de reposição, o tempo de atendimento de chamada, a rastreabilidade e garantia do produto, bem como queixas e reclamações do cliente.

Nota-se que os elementos da pré-transação caracterizam-se pelo acesso do cliente ao produto. Já os elementos da transação correspondem à disponibilidade do produto, observando-se o gerenciamento de estoques, enquanto os elementos da pós-transação correspondem ao fator pós-venda, como a reposição do produto e a assistência técnica.

O efetivo gerenciamento destas três dimensões conduz ao alcance do bom nível de serviço ao cliente, atendendo às utilidades de tempo e lugar, o que leva ao efetivo gerenciamento logístico.

Bowersox e Closs ${ }^{25}$ citam que "o objetivo central da logística é atingir um nível desejado de serviço ao cliente pelo menor custo total possível". Explicam que atualmente o fator restritivo para o alcance de qualquer nível de serviço logístico é econômico e não tecnológico, uma vez que os avanços tecnológicos nos últimos anos foram de elevado porte e, em especial na área de logística, a tecnologia disponível é considerada suficiente para atender as necessidades do cliente. Resta o gerenciamento financeiro, diante das alternativas de tecnologias disponíveis.

Entretanto, para que haja um gerenciamento financeiro efetivo, é necessário ter o suporte de um sistema de informações que forneça tempestivamente as informações necessárias ao processo decisório da logística e, conseqüentemente, se possa avaliar as alternativas de tecnologias existentes, para melhor atender o cliente.

Diante do exposto, percebe-se que para gerenciar eficiente e eficazmente todo o sistema logístico é necessário que haja um suporte informacional ao processo decisório da logística, o que ocorre por meio de um sistema de informações contábeis-gerenciais sinérgico e efetivo. $O$ enfoque necessário ao gerenciamento logístico deve ser o cliente, buscando fornecer um nível de serviço que, no mínimo, atenda as necessidades fundamentais do cliente, mas que procure superar as expectativas deste.

\subsection{A cadeia de valor e os fluxos logísticos}

A preocupação com o nível de serviço logístico ao cliente traz a necessidade de atentar para novos padrões de distribuição moldados pelos clientes. De acordo com Ching ${ }^{26}$, estes padrões demandam a minimização de custos de distribuição, a manutenção do nível crescente de serviço, a garantia de produtos de qualidade, a redução de devoluções por defeitos de manuseio no processo de distribuição, bem como a maximização da resposta rápida à demanda.

Atingir um gerenciamento eficaz e eficiente da cadeia corresponde à essência da vantagem competitiva alvo das empresas. Porter ${ }^{27}$ explica que "toda a empresa é uma reunião de atividades que são executadas para projetar, produzir, comercializar, entregar e sustentar seu produto". Todas estas atividades são apresentadas pelo autor como fontes de vantagem competitiva, onde a vantagem virá da melhor utilização dos recursos bem como das estratégias da empresa.

Bowersox e Closs $^{28}$ citam que a "competência logística decorre de uma avaliação relativa da capacitação de uma empresa para fornecer ao cliente um serviço competitivamente superior, ao menor custo possível". Assim, a obtenção de vantagem competitiva, por meio da competência logística, está centrado na criação de valor para o cliente, ou seja, no nível de serviço logístico ao cliente. É necessário, portanto, identificar as funções que compõem a cadeia, bem como os fluxos logísticos nela existente.

A cadeia de valores, com base na seqüência de funções de negócios dentro da empresa, adicionando utilidade aos produtos ou serviços dentro da organização, é apresentada por Horngren, Foster e

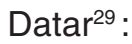

${ }^{25}$ BOWERSOX, Donald J; CLOSS, David J. Logística empresarial: o processo de integração da cadeia de suprimento. São Paulo: Atlas, 2001, p.21.

${ }^{26}$ CHING, Hong Yuh. Gestão de estoques na cadeia de logística integrada: supply chain. São Paulo: Atlas, 1999, p.148.

${ }^{27}$ PORTER, Michael E. Vantagem competitiva: criando e sustentando um desempenho superior. 4.ed. Rio de Janeiro: Campus, 1992, p.33.

${ }^{28}$ BOWERSOX, Donald J; CLOSS, David J. Logística empresarial: o processo de integração da cadeia de suprimento. São Paulo: Atlas, 2001, p.23.

${ }^{29}$ HORNGREN, Charles T.; FOSTER, George; DATAR, Srikant M. Cost accounting: a managerial emphasis. 8.ed. Englewood Cliffs, New Jersey: Prentice-Hall, 1994, p.2-3. 
a) Pesquisa e desenvolvimento - a geração e experimentação de idéias relacionadas a novos produtos, serviços ou processos;

b) Desenho de produtos, serviços ou processos - 0 planejamento detalhado e a elaboração de produtos, serviços ou processos;

c) Produção - a coordenação e a organização de recursos para produzir um produto ou prestar um serviço;

d) Marketing - o processo pelo qual indivíduos ou grupos: (a) aprendem e avaliam as atividades de produtos e serviços; e (b) adquirem esses produtos e serviços; e) Distribuição - o mecanismo pelo qual produtos e serviços são entregues ao consumidor;

f) Serviço ao cliente - atividades de suporte fornecidas aos clientes.

A atividades definidas compreendem as diversas funções desenvolvidas nas empresas que compõem a sua cadeia de valor. Ressalta-se que a importância do sistema logístico está em adicionar valor ao produto, por meio do serviço ao cliente, o que ocorre pela integração de todas as funções apresentadas. As funções definidas pelos autores estão representadas na Figura 2 a seguir.

Figura 2 - A Cadeia de Valor segundo Horngren, Foster e Datar

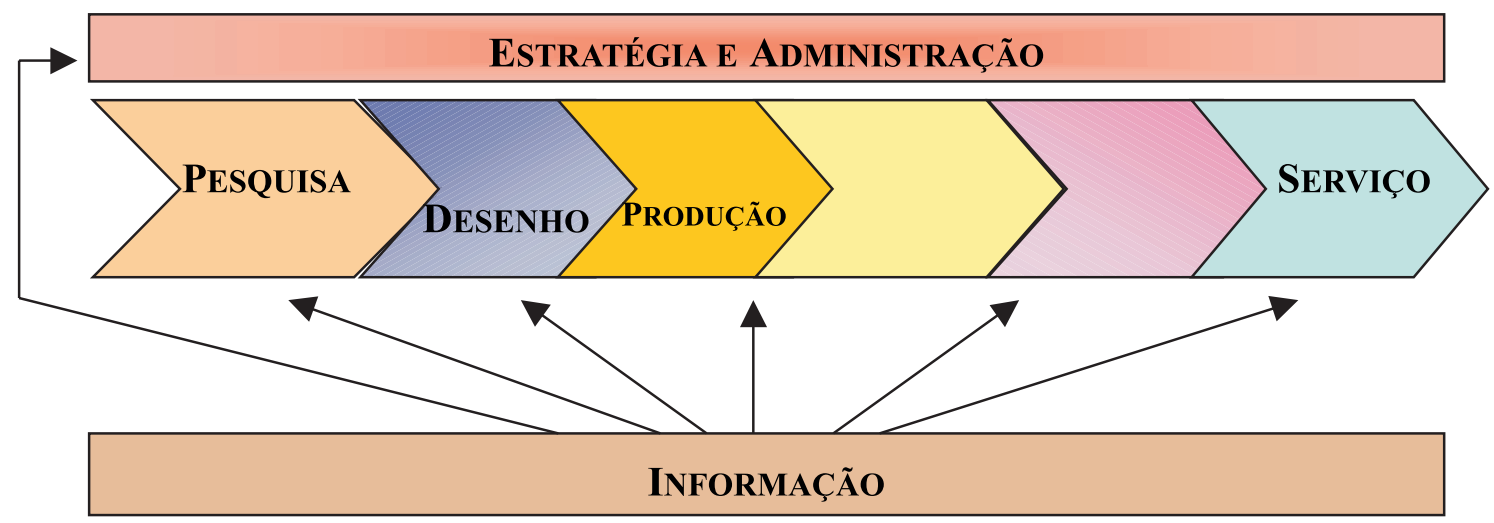

FONTE: Adaptado de HORNGREN, Charles T., FOSTER, George e DATAR, Srikant M. Cost accounting: a managerial emphasis. 8.ed. Englewood Cliffs, New Jersey: Prentice-Hall, 1994, p.3.

Neste sentido, percebe-se os fluxos logísticos na cadeia de valor, ressaltando-se a importância do fluxo de informações como suporte. Horngren, Foster e Datar ${ }^{30}$ explicitam que "os gestores devem conhecer a percepção de seus clientes em relação aos produtos e serviços da empresa". O fluxo informacional surge como ponto fundamen- tal para o sucesso do gerenciamento da cadeia Vale lembrar que o fluxo na cadeia de valor não é representado somente pelo fluxo de informação, mas também pelos fluxos financeiro e de materiais. Esses fluxos logísticos encontram-se representados em conjunto na cadeia de valor, conforme ilustra a Figura 3.

\section{Figura 3 - Fluxos Logísticos na Cadeia de Valor}

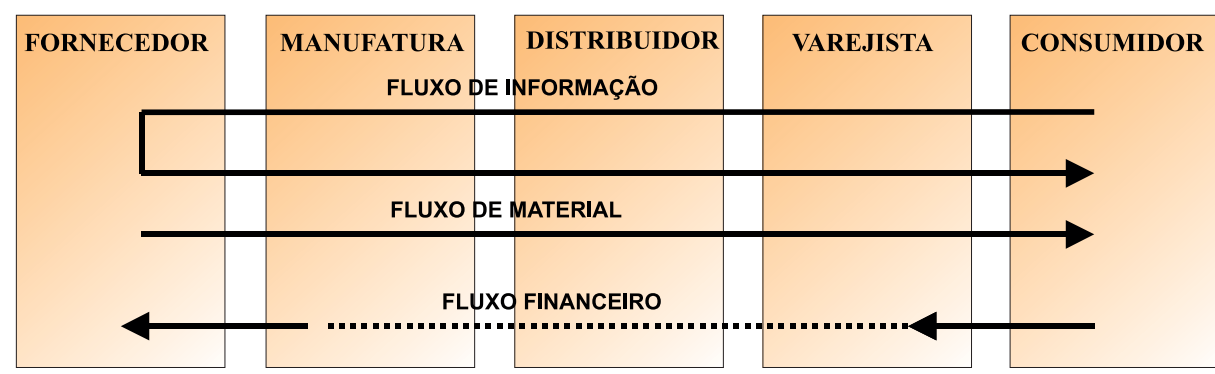

FONTE: NOVAES, Antônio Galvão. Logística e gerenciamento da cadeia de distribuição: estratégia, operação e avaliação. Rio de Janeiro: Campus, 2001, p.38. 
Bowersox, Smykay e La Londe ${ }^{31}$ afirmam que a "qualidade e a velocidade da informação no sistema logístico facilita a integração de todos os centros de atividades de distribuição física da empresa". Uma rede de informação ineficaz pode provocar ineficácias no sistema de distribuição, bem como ao longo da cadeia como um todo, especialmente problemas na programação de compras e de produção.

Dornier et al. ${ }^{32}$ explicam que as tecnologias de informação, como código de barra e o EDI, ajudam a tornar as informações logísticas globais mais confiáveis, bem como a industrializar seu processo e aumentar a velocidade de transferência de informações.

Ballou $^{33}$ cita que "o sistema de informações logísticas é um subsistema de informações gerenciais, que providencia a informação especificamente necessária para a administração logística".

Bowersox e Closs ${ }^{34}$ comentam que "a qualidade da tecnologia utilizada não é acompanhada pela qualidade da informação. Deficiências na qualidade da informação podem criar inúmeros problemas operacionais", como informações incorretas quanto às tendências e aos acontecimentos podem influenciar na projeção das atividades logísticas a serem desempenhadas, bem como informações imprecisas sobre o processamento de pedidos quanto às exigências de um cliente específico.

Atualmente, informações precisas, em tempo hábil, são cruciais para a eficácia do projeto de sistemas logísticos. Bowersox e Closs ${ }^{35}$ citam três razões básicas para tal:

a) são fatores essenciais do serviço ao cliente, informações sobre o status do pedido, disponibilidade do produto, programação de entrega e faturamento;

b) a informação pode ser um instrumento eficaz na redução de estoque e da necessidade de recursos humanos; $\mathrm{e}$ c) a informação aumenta a flexibilidade para decidir como, quando e onde os recursos podem ser utilizados para que se obtenha vantagem competitiva.

Neste sentido complementam, "a tecnologia de informação é o recurso-chave para se obter integração"36. Tal conduz à necessidade de um sistema de informações sinérgico, integrando a cadeia de valor por meio da emissão de relatórios, gerados pelo sistema de informações contábeis-gerenciais, que atendam às necessidades informacionais dos gestores, a fim de dar suporte ao processo decisório da logística em todas as suas etapas: planejamento, execução e controle.

Diante do exposto, cabe ressaltar a relevância da função de distribuição física de produtos, inserida na cadeia de valor, uma vez que esta função é a mais próxima do cliente, alvo do nível de serviço oferecido pela logística. Cabe, então, conhecer as atividades e responsabilidades atribuídas a essa função.

\subsection{Distribuição física de produtos}

A distribuição física de produtos é definida por Ballou ${ }^{37}$ como "o ramo da logística empresarial que trata da movimentação, estocagem e processamento de pedidos dos produtos finais da firma". Ressalta que esta pode ser considerada a atividade mais importante em termos de custos para a maioria das empresas.

Por sua vez, Ching ${ }^{38}$ esclarece que "a logística de distribuição trata das relações da empresa - cliente consumidor, sendo responsável pela distribuição física do produto acabado até os pontos-de-venda ao consumidor e deve assegurar que os pedidos sejam pontualmente entregues".

A entrega de produtos é realizada por meio de canais de distribuição, conforme lembra Arnold ${ }^{39}$ ao citar que a distribuição física corresponde ao "transporte e o armazenamento de produtos acabados desde

\footnotetext{
${ }^{31}$ BOWERSOX, Donald J.; SMYKAY, Edward W.; LA LONDE, Bernard J. Physical distribution management: logistics problems of the firm. 4.ed. Nova York: Macmillan Company, 1970, p.228.

${ }^{32}$ DORNIER, Philippe-Pierre et. Al. Logística e operações globais: textos e casos. São Paulo: Atlas, 2000, p.587.

${ }^{33}$ BALLOU, Ronald H. Logística empresarial: transportes, administração de materiais e distribuição física. São Paulo: Atlas, 1993 , p. 279.

${ }^{34}$ BOWERSOX, Donald J; CLOSS, David J. Logística empresarial: o processo de integração da cadeia de suprimento. São Paulo: Atlas, 2001 , p.39.

${ }^{35}$ Idem, p. 176.

${ }^{36}$ Idem, p.53.

${ }^{37}$ BALLOU, Ronald H. Logística empresarial: transportes, administração de materiais e distribuição física. São Paulo: Atlas, 1993 , p. 40.

${ }^{38} \mathrm{CHING}$, Hong Yuh. Gestão de estoques na cadeia de logística integrada: supply chain. São Paulo: Atlas, 1999, p.147.

${ }^{39}$ ARNOLD, J. R. Administração de materiais: uma introdução. São Paulo: Atlas, 1999, p.375.
} 
o final da produção até o cliente. O caminho particular pelo qual os produtos passam - por centros de distribuição, atacadistas e varejistas - é denominado canal de distribuição".

Neste sentido, a gestão da distribuição física de produtos, de acordo com Slack et al. ${ }^{40}$, corresponde ao conjunto formado pela gestão dos estoques e do sistema de transporte, ligando a unidade produtiva ao consumidor. O processo de tomada de decisões na gestão da distribuição física de produtos pela Logística inclui a localização e quantidade de armazéns, bem como os modais de transporte adotados.

Verifica-se o aporte de responsabilidades atribuídas à função de distribuição física de produtos. Sob esta ótica, a gestão da distribuição física de produtos deve contemplar decisões relacionadas não só à movimentação de cargas, mas também à forma como será realizado este transporte (modais de transporte), os meios de estocagem mais adequados ao produto em questão, além do nível de serviço ao cliente, enfocando os valores agregados ao produto que atendam as necessidades do cliente.

A gestão da distribuição física de produtos ocorre, de acordo com Ballou ${ }^{41}$, em três níveis: estratégico, tático e operacional. O nível estratégico corresponde à decisão de como transportar, como fracionar a carga, como controlar os estoques e à localização dos depósitos. O nível tático equivale à utilização dos recursos disponíveis, sendo normalmente um planejamento a curto prazo. Por sua vez, o nível operacional diz respeito as tarefas diárias desempenhadas a fim de garantir um eficiente fluxo logístico. Tais níveis correspondem ao planejamento, execução e controle, respectivamente, preconizados nesta pesquisa como as etapas do processo decisório.

Um conceito mais recente sobre a função de distribuição física é apresentado por Bowersox e Closs ${ }^{42}$, englobando todas as atividades relacionadas ao fornecimento de serviço ao cliente:

"Estas atividades incluem recebimento e processamento de pedidos, posicionamento de estoques, armazenagem, manuseio e transporte dentro de um canal de distribuição. Incluem a responsabilidade pela coordenação com o planejamento de marketing em áreas como formação de preços, apoio promocional, níveis de serviço ao cliente, padrões de entrega, manuseio de mercadoria devolvida e apoio ao ciclo de vida. $\mathrm{O}$ principal objetivo da distribuição física é ajudar na geração de receita, prestando níveis estrategicamente desejados de serviço ao cliente, ao menor custo total."

Nota-se que as responsabilidades da função de distribuição física de produtos, abrange desde o processamento de pedidos, passa pelo estoque, armazenagem e movimentação, inclui a projeção do preço de venda e apoio promocional, enfoca o nível de serviço ao cliente, e só tem fim no atendimento pós-venda, relacionado à mercadoria devolvida e garantia dos produtos, visando à otimização da receita e à redução do custo total. Este ciclo básico de atividades da distribuição física é apresentado na Figura 4.

\section{Figura 4 - Atividades do ciclo básico de atividades da distribuição física}

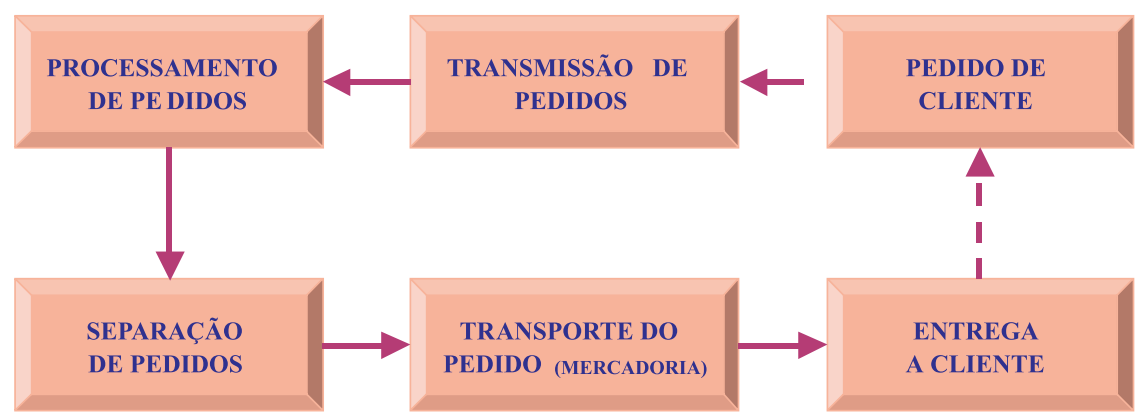

FONTE: BOWERSOX, Donald J; CLOSS, David J. Logística empresarial: o processo de integração da cadeia de suprimento. São Paulo: Atlas, 2001, p.57.

${ }^{40}$ SLACK, Nigel et al. Administração da produção. São Paulo: Atlas, 1997, p.437.

${ }^{41}$ BALLOU, Ronald H. Logística empresarial: transportes, administração de materiais e distribuição física. São Paulo: Atlas, 1993 , p. 43.

${ }^{42}$ BOWERSOX, Donald J; CLOSS, David J. Logística empresarial: o processo de integração da cadeia de suprimento. São Paulo: Atlas, 2001 , p.46. 
Observa-se que são cinco as atividades abrangidas, todas relacionadas à execução física do pedido, desde a solicitação do cliente até a entrega da mercadoria ao mesmo. Kotler ${ }^{43}$ ressalta que, "a maioria das empresas está tentando encurtar o ciclo do pedido até o recebimento - ou seja, o tempo entre o recebimento do pedido, a entrega e o pagamento"; quanto maior o tempo deste ciclo, menor é a satisfação do cliente e menor é o lucro da empresa. Portanto, é preciso atentar para a atividade de processamento do pedido com o intuito de reduzir o tempo desta atividade.

Além disso, Kotler ${ }^{44}$ comenta que, "as operações de transporte afetarão o preço dos produtos, a pontualidade da entrega e as condições dos produtos ao chegarem ao seu destino; todos esses fatores determinam a satisfação do cliente". Dessa forma, torna-se uma atividade chave para incrementar o nível de serviço ao cliente.

É importante destacar que, atualmente, a atividade de transporte do pedido, muitas vezes, ocorre por meio de empresas especializadas neste tipo de serviço. Conseqüentemente, para as empresas que atentam para o nível de serviço ao cliente, faz-se necessário um controle rigoroso do desempenho destas contratações. Neste sentido, Ching ${ }^{45}$ cita que:

"os transportadores maduros não se ocupam apenas com os limites de preço do frete a ser incluído no custo total de logística, mas também com o critério de seleção que passa a ser o de performance no serviço prestado. Isto inclui confiabilidade na entrega, registro de ocorrências, sistema de informação em tempo real, uso de código de barra para meIhorar exatidão de estoque e documentação, uso de sistema de transporte confiável, condições do equipamento, flexibilidade e compromisso para excelência do serviço."

Diante do exposto, torna-se primordial que haja o acompanhamento, no caso da contratação de transportadores na fase de distribuição física dos produtos, do desempenho das mesmas, o que pode ocorrer por meio de relatórios de acompanhamento da pontualidade das entregas, bem como do nível de ocorrências de reclamações dos clientes, ou, ainda, de problemas nas mercadorias gerados durante o transporte, além do rastreamento da carga via satélite.

Novaes ${ }^{46}$ lembra que "o objetivo geral da distribuição física, como meta ideal, é o de levar os produtos certos, para os lugares certos, no momento certo e com o nível de serviço desejado, pelo menor custo possível". Contudo, tal afirmação pode parecer antagônica, segundo o autor, por juntar o desejo de manter elevados níveis de serviço ao cliente com a redução de custos, mas as melhorias no sistema devem ser efetuadas com base no conceito de cadeia de valor e gerenciamento da cadeia integrada.

Percebe-se, então, que a gestão da distribuição física de produtos pela Logística é empregada para dar apoio às decisões de como melhor gerenciar os recursos disponíveis, promovendo um equilíbrio entre as diversas atividades envolvidas no processo, com vistas a um eficiente e eficaz nível de serviço logístico ao cliente.

Diante do exposto, observa-se a relevância da gestão da logística no processo decisório das organizações, visto que envolve decisões relacionadas à cadeia de valor como um todo, desde o suprimento de materiais até à distribuição física de produtos, onde encontra-se o atendimento direto ao cliente. Verificase, portanto, ser a logística uma área de cunho estratégico nas organizações.

\section{A CONTROLADORIA COMO SUPORTE AO PROCESSO DECISÓRIO DA LOGÍSTICA}

A Controladoria é analisada sob a ótica de ramo do conhecimento e de unidade administrativa. Almeida, Parisi e Pereira ${ }^{47}$ afirmam que a Controladoria, enquanto ramo do conhecimento, é responsável pelo estabelecimento das bases teóricas e conceituais necessárias para a modelagem, construção e manutenção dos

\footnotetext{
${ }^{43}$ KOTLER, Philip. Administração de marketing: a edição do novo milênio. 11.ed.. São Paulo: Prentice Hall, 2001 , p.561.

${ }^{44} \mathrm{Idem}$, p.563.

${ }^{45}$ CHING, Hong Yuh. Gestão de estoques na cadeia de logística integrada: supply chain. São Paulo: Atlas, 1999, p.158

${ }^{46}$ NOVAES, Antônio Galvão. Logística e gerenciamento da cadeia de distribuição: estratégia, operação e avaliação. Rio de Janeiro: Campus, 2001, p.145.

${ }^{47}$ ALMEIDA, Lauro Brito de, PARISI, Cláudio, pereira, Carlos Alberto. Controladoria. In: CATELLI, Armando (coord.). Controladoria: uma abordagem da gestão econômica - GECON. São Paulo: Atlas, 1999, p.370.
} 
sistemas de informações, no sentido de suprir adequadamente as necessidades informativas dos gestores e os induzir durante o processo de gestão, quando requeridos, a tomarem decisões ótimas.

Por sua vez, a unidade administrativa, conforme Mosimann e Fisch ${ }^{48}$, "tem por finalidade garantir informações adequadas ao processo decisório, colaborar com os gestores em seus esforços de obtenção da eficácia de suas áreas quanto aos aspectos econômicos e assegurar a eficácia empresarial, também sob os aspectos econômicos, por meio da coordenação dos esforços dos gestores das áreas".

No presente artigo, a Controladoria é visualizada sob o enfoque administrativo, onde possui missão, princípios e funções, definidos de acordo com a gestão empresarial. A função da Controladoria dentro de uma organização, de acordo com Kanitz ${ }^{49}$, consiste em dirigir e implantar os sistemas de:

a) informação - compreende os sistemas contábeis e financeiros da empresa;

b) motivação - refere-se aos efeitos dos sistemas de controle sobre o comportamento das pessoas diretamente atingidas;

c) coordenação - diz respeito à assessoria que o Controlador presta à direção da empresa, sugerindo soluções;

d) avaliação - compreende a interpretação dos fatos e avaliação dos resultados;

e) planejamento - fundamenta-se em determinar se os planos são consistentes e viáveis, aceitos e coordenados, e se podem servir de base para avaliação posterior; e

f) acompanhamento - consiste em acompanhar de perto a evolução dos planos traçados.

O Controller, segundo Garrison apud Mosimann e Fisch ${ }^{50}$, "como gestor do sistema de informações, está em posição de exercer controle por meio do relato e da interpretação dos dados necessários à tomada de decisões". Por conseguinte, a Controladoria está diretamente relacionada ao processo de gestão dentro de uma empresa.
Wilson e Colford apud Figueiredo ${ }^{51}$ definem cinco funções para a Controladoria, a saber:

a) planejamento - estabelecer e manter um plano integrado para as operações compatíveis com os objetivos da empresa, a curto e longo prazo, com análises e divulgação posteriores;

b) controle - desenvolver e revisar constantemente os padrões de avaliação de desempenho, a fim de que se tornem guias, bem como estejam de acordo com os padrões pré-estabelecidos;

c) informação - preparar, analisar e interpretar os resultados financeiros, de forma a serem úteis aos gestores no processo de tomada de decisões, bem como aos usuários externos;

d) contabilidade - delinear, estabelecer e manter o sistema de contabilidade geral e de custos em todos os níveis da empresa, registrando todas as transações e preparando as demonstrações financeiras externas; $e$

e) outras funções - administrar e supervisionar cada uma das atividades que impactam o desempenho empresarial, dentre elas o envolvimento com auditores internos e externos, bem como autoridades fiscais.

As funções da Controladoria apresentadas pelos autores são semelhantes em conteúdo, diferenciando-se, algumas vezes, quanto à classificação. Contudo, percebe-se que as funções da Controladoria fundamentam-se no tripé planejamento, execução e controle.

Deve-se ressaltar que entre as funções da Controladoria, segundo Roehl-Anderson e Bragg ${ }^{52}$, está "o relato preciso da informação. A integridade da função deve ser preservada no sentido de ser útil". Figueiredo ${ }^{53}$ destaca que ela tem a missão de "zelar pela continuidade da empresa assegurando a otimização do resultado global".

Denota-se pelo exposto que a Controladoria contribuirá para o processo de gestão empresarial exercendo suporte por meio de um sistema de informações eficaz e sinérgico entre os gestores, zelando pela maximização do resultado da empresa.

\footnotetext{
${ }^{48}$ MOSIMANN, Clara Pellegrinello, FISCH, Sílvio. Controladoria: seu papel na administração de empresas. 2. ed. São Paulo: Atlas, 1999 , p.88.

${ }^{49}$ KANITZ, Stephen Charles. Controladoria: teoria e estudos de caso. São Paulo: Pioneira, 1976, p.7-8.

${ }^{50}$ MOSIMANN, Clara Pellegrinello, FISCH, Sílvio. Controladoria: seu papel na administração de empresas. 2. ed. São Paulo: Atlas, 1999 , p.89.

${ }^{51}$ FIGUEIREDO, Sandra Maria. Contabilidade e a gestão empresarial. Revista Brasileira de Contabilidade. Brasília, ano XXIV, n. ${ }^{\circ}$ 93, p.20-34, maio/junho 1995, p.25. ${ }^{52}$ ROEHL-ANDERSON, Janice M., BRAGG, Steven M. The controller's function: the work of the managerial accountant. Nova York: John Wiley \& Sons, 1996 , p.6.

${ }^{53}$ FIGUEIREDO, Sandra Maria. Contabilidade e a gestão empresarial. Revista Brasileira de Contabilidade. Brasília, ano XXIV, n. ${ }^{\circ} 93$, p.20-34, maio/junho 1995, p.25.
} 
Uma vez levantadas as características da gestão da logística, em especial da função de distribuição física dos produtos, torna-se evidente a necessidade de as organizações reagirem frente às pressões deste setor, tanto interno quanto externo.

As organizações são orientadas para a otimização

Figura 5 - Organograma básico da organização de resultado, que é viabilizado por meio do processo de gestão empresarial, a fim de garantir sua sobrevivência. O processo de gestão empresarial é assistido pela Controladoria, enquanto unidade administrativa gerenciadora do sistema de informações, no processo de tomada de decisões, conforme mostra a Figura 1.

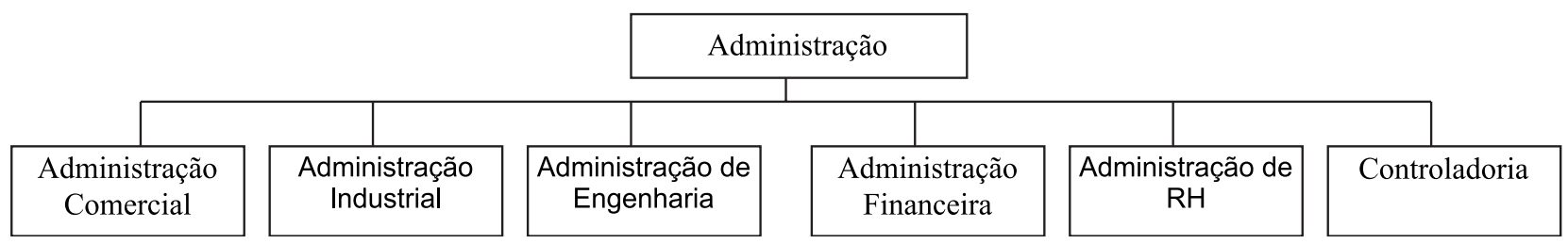

FONTE: RICCIO, Edson Luiz. Conceitos de controladoria. São Paulo: FEA / USP, 1995.(mimeo)

Observa-se a relação da unidade de Controladoria com a administração geral, encontrando-se no mesmo patamar das demais unidades administrativas operacionais com a função de fornecer suporte informacional, tanto à administração geral, quanto às demais unidades.

Oliveira ${ }^{54}$ cita que, dentro dos modernos conceitos de gestão, "uma controladoria eficiente e eficaz deve estar capacitada a organizar e reportar dados e informações relevantes e exercer uma força capaz de influir nas decisões dos gestores da entidade". Em outras palavras, a Controladoria deve ser capaz de influenciar positivamente o processo decisório, com base em seu potencial informacional.

Tal influência deve levar à melhoria dos sistemas de controle gerenciais, bem como, conseqüentemente, a uma maior eficiência e eficácia no desempenho dos gestores, lembrando sempre da importância de um sistema de informação compatível com a comunicação e negociações decorrentes do processo de globalização.

Dentro da estrutura apresentada, é importante ressaltar a representação de um comitê executivo de Controladoria, voltado ao planejamento e controle de uma empresa, que conforme Riccio ${ }^{55}$, seria dado como evidenciado na Figura 2.

\section{Figura 6 - Organograma de um Comitê Executivo de Controladoria}

\begin{tabular}{|c|c|c|c|}
\hline & Contro & oria & \\
\hline$\Gamma$ & $T$ & $T$ & \\
\hline Contabilidade Geral & Custos & $\begin{array}{l}\text { Planejamento } \\
\text { e Controle }\end{array}$ & Auditoria \\
\hline $\begin{array}{l}\text { Contabilidade } \\
\text { Financeira } \\
\text { Gerencial } \\
\text { Fiscal }\end{array}$ & $\begin{array}{l}\text { Contabilidade de Custos } \\
\text { Análise de Produtividade } \\
\text { Análise de Custos }\end{array}$ & $\begin{array}{l}\text { Planej. e Orçamento } \\
\text { Controle Gerencial } \\
\text { Estudos de Fatores ext. } \\
\text { Projetos Especiais }\end{array}$ & $\begin{array}{l}\text { Auditoria Operacional } \\
\text { Auditoria Contábil } \\
\text { Auditoria Externa }\end{array}$ \\
\hline
\end{tabular}

FONTE: RICCIO, Edson Luiz. Conceitos de controladoria. São Paulo: FEA / USP, 1995.(mimeo)

\footnotetext{
${ }^{54}$ OLIVEIRA, Luís Martins de. Controladoria: conceitos e aplicações. São Paulo: Futura, 1998, p.19.

${ }^{55}$ RICCIO, Edson Luiz. Conceitos de controladoria. São Paulo: FEA / USP, 1995.(mimeo)
} 
Verifica-se, portanto, a Controladoria entrelaçada com a gestão empresarial, dentro de uma organização, exercendo seu papel de suporte informacional, por meio da contabilidade geral, contabilidade de custos, do planejamento e controle e da auditoria.

Neste contexto, o desempenho da Controladoria, enquanto provedora de informações econômico-financeiras, a fim de incrementar a eficiência e eficácia do processo gerencial e proteção dos interesses da empresa, ocorre por meio do tratamento dos dados operacionais, no sistema de informações contábeis, atrelado a dados sobre as ameaças e oportunidades, pontos fracos e fortes da organização e outros conhecimentos que vão além da área contábil, com o intuito de gerar e disponibilizar informações úteis aos gestores no processo de tomada de decisões.

\section{METODOLOGIA DA PESQUISA}

Segundo Gil"56, as pesquisas exploratórias "são desenvolvidas com objetivo de proporcionar visão geral, de tipo aproximativo, acerca de determinado fato". O fato a ser explorado nesta pesquisa consiste no suporte da Controladoria ao processo decisório da Logística, na gestão da distribuição física de produtos, enquanto gerenciadora do sistema de informações e caracteriza-se como um estudo exploratório por levar a novas descobertas nesta área. Gil ${ }^{57}$ explica que as pesquisas exploratórias "envolvem levantamento bibliográfico e documental, entrevistas não padronizadas e estudos de caso", que serão as ferramentas utilizadas para dar andamento ao estudo.

O tratamento dos dados coletados foi de natureza predominantemente qualitativa, visto que o método qualitativo, de acordo com Richardson ${ }^{58}$, "difere do quantitativo à medida que não emprega um instrumental estatístico como base do processo de análise de um problema". Ressalta-se que o aspecto qualitativo da investigação pode apresentar-se inclusive em informações colhidas de forma quantitativa, tendo em vista não perderem seu caráter qualitativo.

Portanto, o presente estudo consubstancia-se em pesquisa qualitativa de caráter exploratório desenvolvida por meio de levantamento documental e bibliográfico, e estudo de multicasos, caracterizando-se como uma pesquisa de corte transversal.

O objeto de estudo desta pesquisa constitui-se das empresas de capital aberto que possuem em sua estrutura organizacional os setores de Controladoria e de Logística, localizadas no Estado de Santa Catarina, por intermédio dos Gestores das empresas, nas áreas de Controladoria e Logística, enquanto elementos de investigação dentro do objeto de estudo escolhido.

O contato com as empresas foi feito com base em uma listagem, obtida via internet ${ }^{59}$ na homepage da Comissão de Valores Mobiliários CVM, órgão normatizador das empresas de capital aberto no Brasil. Além disso, dados ${ }^{60}$ referentes ao número de empregados das empresas de capital aberto do Estado de Santa Catarina, foram obtidos junto à Federação das Indústrias do Estado de Santa Catarina - FIESC.

Dessas duas listagens foram selecionadas onze empresas de capital aberto, com número de empregados superior a dois mil e trezentos. Visto que para a realização da pesquisa eram necessárias empresas que possuíssem em sua estrutura organizacional as áreas de Controladoria e de Logística, partiu-se do pressuposto de que haveria maior probabilidade de encontrar esta característica em empresas de grande porte com um elevado número de empregados.

Dentre estas somente três empresas concordaram em participar da pesquisa, enquanto quatro outras, após diversos contatos, não se manifestaram quanto à disponibilidade e interesse em participar da pesquisa: uma alegou não haver disponibilidade para participar; duas demonstraram

${ }^{56} \mathrm{GIL}$, Antônio Carlos. Métodos e técnicas de pesquisa social. São Paulo: Atlas, 1995, p. 45.

${ }^{57}$ Idem, p. 44.

${ }^{58}$ RICHARDSON, Roberto J. Pesquisa social: métodos e técnicas. 2.ed. São Paulo: Atlas, 1989, p.38.

${ }^{59}$ COMISSÃO DE VALORES MOBILIÁRIOS - CVM. Cadastro geral. Disponível em: <http://www.cvm.gov.br>. Acessado em: 09 de abril 2001

${ }^{60}$ SISTEMA FEDERAÇÃO DAS INDÚSTRIAS DO ESTADO DE SANTA CATARINA. Guia da Indústria de Santa Catarina 2000. Florianópolis: FIESC, maio/2000. 
desinteresse na pesquisa, e a última, apesar de ser uma empresa do Estado de Santa Catarina e mostrar-se bastante interessada, seu processo de gestão está sediado em São Paulo, o que inviabilizou sua participação.

Para não revelar a razão social das empresas pesquisadas, no sentido de manter o sigilo quanto às estratégias adotadas em relação ao tema investigado, atribuiu-se, aqui, a denominação de Empresa A, Empresa B e Empresa C.

Portanto, a amostra selecionada caracterizase pela intencionalidade, que para Barros e Lehfeld $^{61}$ corresponde àquela em que o pesquisador "se dirige intencionalmente a grupos de elementos dos quais deseja saber a opinião", os quais são escolhidos de acordo com uma estratégia adequada às características estabelecidas, bem como pela acessibilidade das empresas consultadas.

A fim de realizar as entrevistas foi elaborado um roteiro de perguntas, que, segundo Gil62, corresponde à "técnica de investigação composta por um número mais ou menos elevado de questões apresentadas por escrito às pessoas, tendo por objetivo o conhecimento de opiniões, crenças, sentimentos, interesses, expectativas, situações vivenciadas, etc".

Com o objetivo de responder ao problema de pesquisa, os dados foram coletados por meio de observação sistemática. Para Marconi e Lakatos $^{63}$, corresponde àquela em que se "utiliza instrumentos para a coleta de dados ou fenômenos observados (...). Todavia, as normas não devem ser padronizadas nem rígidas demais".

Consideram-se como dados aqueles obtidos nas entrevistas semi-estruturadas e no exame de documentos. As entrevistas semi-estruturadas foram conduzidas pela autora do trabalho, bem como a investigação de documentos. Em relação aos dados secundários, estes foram obtidos por meio da consulta de publicações, documentos internos e outros relacionados ao problema de pesquisa.

\section{DESCRIÇÃO E ANÁLISE DOS DADOS COLETADOS}

Este tópico descreve o papel que a Controladoria exerce enquanto órgão administrativo nas empresas pesquisadas em relação à gestão da distribuição física de produtos, realizada pela Logística. A descrição e análise dos dados está alicerçada no relato dos Controllers e gestores da Distribuição Física de Produtos das três empresas.

\subsection{Empresa A}

Na Empresa A, o Controller age como um guardião das metas e objetivos a serem alcançados pela empresa como um todo. Caso seja detectado algum problema quanto ao alcance destas metas, com base nos indicadores determinados na fase de planejamento, cabe a ele verificar o que está acontecendo e chamar atenção do gestor responsável pela ocorrência. Sendo assim, existe uma constante sinergia entre o Controller e os gestores das demais áreas. Porém, isto é restrito às diretorias, 0 que leva à falta de contato direto com o gestor da distribuição física de produtos.

Como sistema de acompanhamento deste dia-a-dia, (...) mês-a-mês junta-se a diretoria, apresentam-se os números que compunham a meta, e o pessoal que está na reunião tem que responder por estes números, se alcançou, ou se não alcançou e por quê não alcançou. É uma reunião corporativa, que se dá na planta, através de videoconferência e cada planta reporta todos os seus indicadores, mensalmente. Qualquer coisa que apresente um desvio para baixo, acima de três por cento, tem que ter um relatório de três gerações, este relatório (...) seria a identificação das causas e porquê houve esta variação e, em seguida, quais são as ações que você está tomando para retomar a meta. (Controller)

O gestor da distribuição física de produtos recebe relatórios contábeis-gerenciais que utiliza em todas as fases de seu processo decisório, existindo apenas algumas informações que julga necessário

\footnotetext{
${ }^{61}$ BARROS, Aidil Jesus Paes de; LEHFELD, Neide Aparecida de Souza. Fundamentos de metodologia: um guia para a iniciação científica. São Paulo: McGraw-Hill, 1986, p.107. ${ }^{62} \mathrm{GIL}$, Antonio Carlos. Métodos e técnicas de pesquisa social. São Paulo: Atlas, 1995, p.124.

${ }^{63}$ MARCONI, Marina de Andrade, LAKATOS, Eva Maria. Técnicas de pesquisa: planejamento e execução de pesquisas, amostragens e técnicas de pesquisa, elaboração, análise e interpretação de dados. 2.ed. São Paulo: Atlas, 1990, p.81.
} 
receber. No entanto, estas não são disponibilizadas pelo sistema de informações, visto que seria necessário utilizar um sistema logístico mais avançado que o atualmente existente na empresa, a fim de obter tais informações.

Foram citadas diferentes informações utilizadas pela gestão da distribuição física de produtos, realizada pela Logística. O gestor da distribuição física de produtos relatou utilizar informações sobre o volume de produção e vendas; o orçamento de pessoal, de despesas e de investimentos; e custos de transformação e de frete, além dos relatórios legais. Tais informações estão contidas nos relatórios contábeisgerenciais gerados pela Controladoria.

Por outro lado, o gestor da distribuição física de produtos também disse necessitar de informações sobre a programação de navios, pedidos em carteira, lead time de preparação da entrega e reclamações dos clientes. Porém, considera que esta informação poderá ser fornecida por um programa de exportação mais avançado do que o atualmente utilizado pela empresa, sem que seja responsabilidade da Controladoria, tendo em vista que não é ela quem gerencia o sistema de informações.

A Controladoria da Empresa A, enquanto órgão administrativo, exerce seu papel de zelar pela continuidade da empresa, buscando a otimização de resultados e do emprego dos recursos materiais e humanos disponíveis. Por sua vez, o Controller desempenha seu papel de integrar as diversas áreas de responsabilidade para coordenar o planejamento, a organização, o direcionamento e a mensuração das atividades desenvolvidas na empresa.

\subsection{Empresa B}

Na Empresa B, a Controladoria não se apresenta como gerenciadora do sistema de informações e os gestores das demais áreas possuem autonomia em relação à configuração dos relatórios gerenciais. O gestor responsável pela gestão da distribuição física de produtos providencia a configuração dos relatórios que Ihe darão suporte durante o processo decisório junto ao Departamento de Sistemas, o qual é responsável pelo sistema de informações. Diante do exposto, observa-se que, também na Empresa $B$, não existe contato direto entre o Controller e o gestor da Logística de distribuição.

$A$ autonomia entre as áreas, existente na Empresa $B$, é um fator predominante para que a função da Contoladoria não seja exercida na forma de acompanhamento permanente das atividades. Uma vez que os gestores têm autonomia, tanto para a decisão, quanto para configuração de relatórios, junto ao Departamento de Sistemas, a Controladoria somente exerce suporte à cúpula administrativa da empresa e seus relatórios contábeis-gerenciais enfocam números do macroambiente interno da empresa, englobando as controladas do grupo.

O gestor da Logística informou ser importante para o seu processo decisório a informação do número de peças previsto para o período, informação esta que ele retira do orçamento anual fornecido pela Controladoria. Com base nesta informação ele pode prever a quantidade de pessoal que ele precisará para movimentar estas peças, bem como organizar o espaço físico para estoque e fazer o planejamento do volume de entregas a serem realizadas.

Além disso, destacou serem relevantes relatórios sobre a pontualidade de entregas, reclamações de clientes e custo do frete. Contudo, explicou que já tem estes relatórios, sendo estes configurados por ele próprio com o auxílio do Departamento de Sistemas.

Neste sentido, a Controladoria, na Empresa B, exerce sua função de buscar a maximização do resultado global da empresa. Contudo, o Controllernão interfere na integração das áreas, nem procura viabilizar as sinergias existentes, a fim de que o desenvolvimento das atividades, em conjunto, alcance resultados superiores àqueles atingidos de forma independente.

\subsection{Empresa C}

Na Empresa C, a Controladoria encontra-se configurada como gerenciadora do sistema de in- 
formações e trabalha com conceitos de tecnologia de informações que auxiliam o processo decisório na empresa, além de agir em conformidade com a filosofia de "times" proposta pela empresa.

Desta forma, o gestor da distribuição física de produtos tem, além dos relatórios configurados de acordo com a sua necessidade, as informações que precisa, por exemplo os indicadores de desempenho que são de seu interesse. Além disso, o Controller se apresenta como um consultor da área de Controladoria, que lhe oferece todo o apoio necessário, desde pesquisas mercadológicas, até identificação de problemas em relação a otimização do resultado.

O gestor da distribuição física de produtos informou receber relatórios que lhe fornecem informações referentes ao fluxo de caixa, à demonstração do resultado do exercício, ao orçamento geral, custos fixos, de frete e de pessoal, bem como às metas a serem atingidas pela empresa e pelo setor. Tais informações constam nos relatórios gerenciais fornecidos com periodicidade mensal e semanal, além dos relatórios legais.

Expressou também sua preocupação em relação a um controle mais rigoroso da movimentação de peças entre a expedição, as unidades de empreendimento e as transportadoras, bem como aos clientes, principalmente em relação aos depósitos no exterior. A solução para este problema já está sendo providenciada junto a Controladoria, uma vez que esta gerencia o sistema de informações.

Diante do exposto, observa-se que a Controladoria na Empresa C não somente zela pela otimização dos resultados globais da empresa. O Controller age constantemente em busca da integração das atividades desenvolvidas, por meio do acompanhamento efetivo das mesmas, bem como pelo gerenciamento do sistema de informações, o que permite viabilizar um processo de gestão empresarial sinérgico e conjunto, a fim de atingir com eficiência e eficácia as metas estabelecidas pela empresa.

\subsection{Análise conjunta das empresas pesquisada}

Verificou-se, na descrição e análise dos dados de cada uma das empresas pesquisadas, que as atribuições da Controladoria são configuradas de modo diferente, nas três empresas, em relação ao gerenciamento do sistema de informações. Isto traz, como conseqüência, diferenças também no suporte informacional exercido pela mesma à gestão da distribuição física de produtos pela logística.

Todas as empresas trabalham com sistemas integrados de gestão, o que leva ao compartilhamento das informações de forma ágil e eficiente, sendo diferente a responsabilidade atribuída ao gerenciamento do sistema. Nas três empresas a Controladoria é responsável por alimentar estes sistemas com a informação contábil, bem como por gerar projeções fundamentadas nos resultados esperados. Contudo, na Empresa A e na Empresa B o gerenciamento da informação não é responsabilidade da Controladoria, enquanto que na Empresa $\mathrm{C}$ o sistema é gerenciado pela Controladoria.

Neste sentido, verifica-se não haver congruência em relação ao papel da Controladoria, enquanto gerenciadora do sistema de informações, nas três empresas pesquisadas. Contudo há congruência em relação às informações utilizadas no processo decisório da Logística, enfocado aqui na gestão da distribuição física de produtos. Esta assertiva fica evidente quando da análise das necessidades informacionais de cada um dos gestores, havendo diferença apenas na forma de obtenção destas informações.

Apesar de agir como gerenciadora do sistema de informações em apenas uma das empresas pesquisadas, a Controladoria exerce sua função de suporte ao planejamento, execução e controle, isto é, ao longo do processo decisório, nas três empresas. Ela visa a otimização do resultado global da empresa, por meio da coordenação das atividades, acompanhamento e avaliação dos resultados, bem como pelo relato destes resultados. 
O Quadro 1 apresenta uma síntese dos aspectos observados nas três empresas pesquisadas a fim de encaminhar as conclusões a respeito da análise das mesmas.

\section{Quadro 1 - Síntese dos aspectos analisados}

\begin{tabular}{|c|c|c|c|}
\hline & Empresa A & Empresa B & Empresa C \\
\hline $\begin{array}{l}\text { Gestão da distribuição física de } \\
\text { produtos }\end{array}$ & $\begin{array}{l}\text { Abrange a movimentação do } \\
\text { produto acabado desde o rece- } \\
\text { bimento da produção, sua con- } \\
\text { ferência, estocagem, embala- } \\
\text { gem, carregamento e entrega } \\
\text { ao cliente. } \\
\text { O elemento norteador é o nível } \\
\text { de serviço ao cliente e as prin- } \\
\text { cipais decisões estão relaciona- } \\
\text { das ao custo de frete, à } \\
\text { contratação dos meios de trans- } \\
\text { porte, à pontualidade nas entre- } \\
\text { gas e às reclamações dos cli- } \\
\text { entes. }\end{array}$ & Idem & Idem \\
\hline Papel do Controller & $\begin{array}{l}\text { Guardião das metas e objetivos } \\
\text { a serem alcançados pela em- } \\
\text { presa como um todo. }\end{array}$ & $\begin{array}{l}\text { Fornecer suporte em nível de } \\
\text { diretorias, analisando a } \\
\text { corporação como um todo, in- } \\
\text { cluindo as controladas. }\end{array}$ & $\begin{array}{l}\text { Gerenciar o sistema de infor- } \\
\text { mações, exercendo, ainda, o } \\
\text { papel de consultor em projetos } \\
\text { da empresa. }\end{array}$ \\
\hline $\begin{array}{l}\text { Relatórios gerados e sua re- } \\
\text { levância no processo de ges- } \\
\text { tão da distribuição física de } \\
\text { produtos }\end{array}$ & $\begin{array}{l}\text { Volume de produção e vendas; } \\
\text { Orçamento de pessoal, despe- } \\
\text { sa e investimentos; e Custos de } \\
\text { transformação e de frete. }\end{array}$ & Orçamento anual. & $\begin{array}{l}\text { Demonstração do resultado do } \\
\text { exercício; Fluxo de caixa; } \\
\text { Orçamento geral; Relatórios de } \\
\text { custos fixos, de frete e de pes- } \\
\text { soal; e Metas a serem atingi- } \\
\text { das pela empresa e por área. }\end{array}$ \\
\hline $\begin{array}{l}\text { Relatórios não gerados e sua } \\
\text { relevância no processo de ges- } \\
\text { tão da distribuição física de } \\
\text { produtos }\end{array}$ & $\begin{array}{l}\text { Programação de navios; } \\
\text { Pedidos em carteira; Lead time } \\
\text { de preparação da entrega; e } \\
\text { Reclamações dos clientes. }\end{array}$ & $\begin{array}{l}\text { Pontualidade das entregas; } \\
\text { Reclamações de clientes; e } \\
\text { Custo de frete. }\end{array}$ & $\begin{array}{l}\text { Controle on line da movimen- } \\
\text { tação de peças entre a expe- } \\
\text { dição, unidades de empreen- } \\
\text { dimento e as transportadoras, } \\
\text { bem como aos clientes e de- } \\
\text { pósitos no mercado externo. }\end{array}$ \\
\hline
\end{tabular}

\section{CONCLUSÕES}

A verificação do suporte informacional da Controladoria para o processo decisório da Logística, com vistas à função de distribuição física dos produtos nas três empresas pesquisadas, conduz às constatações a seguir apresentadas.

Verificou-se que a gestão da distribuição física de produtos em cada uma das empresas pesquisadas apresenta-se de forma ordenada. Nas três empresas os gestores relataram ser importante, no processo decisório, ter informações relacionadas à pontualidade das entregas, nível de satisfação dos clientes, custos de transporte e movimentação da carga, níveis de produção e previsão de vendas, bem como a situação de estoque no exterior.

O elemento norteador dos gestores da Logística tem como base o nível de serviço logístico ao cliente, que envolve a entrega do produto certo, na hora certa, no local previamente determinado, ao menor custo total possível. Quanto às pessoas envolvidas nas etapas do processo decisório, constatou-se algumas diferenças, visto que em uma das empresas todos participam do processo, noutra apenas duas pessoas e na terceira apenas três pessoas. Contudo, em duas, das três empresas, a decisão final é do gestor do setor e em apenas uma delas a decisão é compartilhada com mais dois líderes do grupo. 
Observou-se também que, a fim de propiciar um suporte informacional ao processo decisório da Logística com vistas à distribuição física de produtos, a Controladoria disponibiliza relatórios contábeisgerenciais. Porém, estes relatórios são emitidos enfocando a empresa como um todo e não a gestão da distribuição física de produtos em particular. Por exemplo, são disponibilizados para todos os órgãos administrativos da empresa o orçamento anual geral, com base em projeções de vendas, e as demonstrações contábeis preconizadas por lei para as empresas de capital aberto, que são o Balanço Patrimonial, a Demonstração do Resultado do Exercício, a Demonstração das Mutações do Patrimônio Líquido e a Demonstração das Origens e Aplicações de Recursos.

Em relação aos relatórios gerenciais, a responsabilidade pela emissão de relatórios específicos para a gestão da distribuição física de produtos em uma das empresas é da Controladoria, nas outras não. No entanto, todos os gestores têm acesso à maioria dos relatórios que julgam importante, mesmo que não sejam emitidos pela Controladoria, uma vez que todas as empresas trabalham com softwares de gestão, os quais são integrados e alimentados diariamente e, por isso, oferecem informações atualizadas.

Nas empresas em que a Controladoria não gerencia o sistema de informações, a configuração dos relatórios gerenciais é feita pelo próprio gestor da distribuição física de produtos, junto ao pessoal da área de sistemas, o que leva a um nível de compreensibilidade e tempestividade equiparado à necessidade de cada gestor. Isto ocorre também na empresa em que a Controladoria gerencia o sistema de informações, com a diferença apenas de que a responsabilidade é da própria Controladoria e não de uma área de sistemas.

Em relação à intensidade de uso dos relatórios contábeis-gerenciais gerados pela Controladoria foi citado como sendo constante. Houve diferenças apenas quanto ao tipo e quantidade de relatórios gerados para a área. Por exemplo, na fase de planejamento, o relatório apontado como de maior intensidade de uso é o orçamento, que inclui a previsão de vendas e é elaborado apenas uma vez ao ano, mas serve de parâmetro durante todo o ano para comparação com o que está se realizando. Nas fases de execução e de controle, todos os demais relatórios são utilizados, bem como toda a informação contábilgerencial pode ser útil. Por este motivo, tais informações estão sempre disponíveis no sistema.

Constatou-se que dentre os relatórios relevantes à gestão da distribuição física de produtos, realizada pela Logística, foram elencados predominantemente o controle da pontualidade das entregas, o controle do custo de transporte das mercadorias, o controle de ocorrência de reclamações por parte do cliente e o controle do nível de estoques, tanto na sede quanto em depósitos no exterior. Tais relatórios são utilizados intensamente pelos gestores em todas as fases do processo decisório. Porém, como o gerenciamento do sistema de informações é realizado pela Controladoria em apenas uma das empresas pesquisadas, conforme salientado anteriormente, estes relatórios são gerados pela Controladoria somente nesta empresa; nas outras existe um departamento de sistemas, o qual é responsável pela emissão dos mesmos.

Ressalta-se que a Controladoria é o órgão responsável por alimentar o sistema de informações com os dados provenientes da Contabilidade, bem como por analisar as informações processadas e divulgálas por meio dos relatórios contábeis-gerenciais. Constatou-se que a Controladoria, em cada uma das empresas, exerce suas funções de coordenação, acompanhamento e avaliação dos resultados planejados e alcançados pela empresa, analisando-os de maneira global, mas agindo localmente, ou seja, verificando as ocorrências e indicando soluções para cada área, conforme a necessidade.

A divergência encontrada está em relação ao gerenciamento do sistema de informações. Tais relatórios somente são emitidos de forma específica para as demais áreas pela Controladoria quando esta é responsável pelo gerenciamento do sistema de informações, o que ocorre apenas em uma das empresas. Caso contrário, tais relatórios são configurados e emitidos por outro órgão, em geral a área de sistemas, o que ocorre em duas das empresas entrevistadas.

Verificou-se que há convergências em relação às atribuições do Controller, uma vez que a organização dos recursos humanos e materiais disponíveis, bem como a mensuração dos resultados, são responsabilidades atribuídas ao Controller em 
cada uma das empresas objeto de estudo. Até mesmo a mensuração dos resultados ocorre por meio dos indicadores de desempenho, sendo que o Controller coordena o direcionamento das atividades a fim de alcançar os objetivos almejados.

No que diz respeito à gestão da distribuição física de produtos, apurou-se, mediante a descrição dos gestores da área de Logística, que o processo decisório é convergente no que se refere aos tipos de decisão e ao elemento norteador do processo. Todavia, apresenta-se divergente quanto ao número de pessoas envolvidas no processo. Por exemplo, em uma das empresas todos os colaboradores do setor participam do processo, enquanto noutra, apenas duas pessoas participam.

A partir do que foi exposto, conclui-se que os relatórios contábeis-gerenciais gerados pela Controladoria com vistas à função da distribuição física de produtos, em geral, não são emitidos de forma específica para o processo decisório da Logística, visto que esta particularidade somente ocorre a partir do momento em que a Controladoria gerencia o sistema de informações; todavia, nas empresas pesquisadas esta função é atribuída à Controladoria em apenas uma das empresas.

Cabe ressaltar que, apesar de não ocorrer o gerenciamento do sistema de informações pela Controladoria nas três empresas pesquisadas, o Controller cumpre com o seu papel de coordenar o planejamento, o acompanhamento e a avaliação das atividades, a fim de alcançar a otimização dos resultados globais da empresa.

\section{REFERÊNCIAS BIBLIOGRÁFICAS}

ALMEIDA, Lauro Brito de, PARISI, Cláudio, pereira, Carlos Alberto. Controladoria. In: CATELLI, Armando (coord.). Controladoria: uma abordagem da gestão econômica - GECON. São Paulo: Atlas, 1999.

ARNOLD, J. R. Administração de materiais: uma introdução. São Paulo: Atlas, 1999.

BALLOU, Ronald H. Logística empresarial: transportes, administração de materiais e distribuição física. São Paulo: Atlas, 1993.

BARROS, Aidil Jesus Paes de; LEHFELD, Neide Aparecida de Souza. Fundamentos de metodologia: um guia para a iniciação científica. São Paulo: McGraw-Hill, 1986.

BOWERSOX, Donald J.; SMYKAY, Edward W.; LA LONDE, Bernard J. Physical distribution management: logistics problems of the firm. 4.ed. Nova York: Macmillan Company, 1970.

BOWERSOX, Donald J; CLOSS, David J. Logística empresarial: o processo de integração da cadeia de suprimento. São Paulo: Atlas, 2001.
CHIAVENATO, Idalberto. Iniciação à administração de materiais. São Paulo: Makron Books, 1991.

CHING, Hong Yuh. Gestão de estoques na cadeia de logística integrada: supply chain. São Paulo: Atlas, 1999.

CHRISTOPHER, Martin. Logística e gerenciamento da cadeia de suprimentos: estratégias para a redução de custos e melhoria dos serviços. São Paulo: Pioneira, 1997.

COMISSÃO DE VALORES MOBILIÁRIOS - CVM. Cadastro geral. Disponível em: <http:// www.cvm.gov.br>. Acessado em: 09 de abril 2001.

COUNCIL OF LOGISTICS MANAGEMENT - CLM. Definição de logística dada pelo CLM. Disponível em: <http://www.clm1.org/index.asp>. Acessado em: 31 de janeiro 2001.

DORNIER, Philippe-Pierre et. Al. Logística e operações globais: textos e casos. São Paulo: Atlas, 2000. 
FIGUEIREDO, Sandra Maria. Contabilidade e a gestão empresarial. Revista Brasileira de Contabilidade. Brasília, ano XXIV, n. 93, p.20-34, maio/junho 1995.

Contabilidade e a gestão empresarial. Revista Brasileira de Contabilidade. Brasília, ano XXIV, n. 9 93, p.20-34, maio/junho 1995.

GIL, Antônio Carlos. Métodos e técnicas de pesquisa social. São Paulo: Atlas, 1995.

HORNGREN, Charles T.; FOSTER, George; DATAR, Srikant M. Cost accounting: a managerial emphasis. 8.ed. Englewood Cliffs, New Jersey: Prentice-Hall, 1994.

KANITZ, Stephen Charles. Controladoria: teoria e estudos de caso. São Paulo: Pioneira, 1976.

KOTLER, Philip. Administração de marketing: a edição do novo milênio. 11.ed.. São Paulo: Prentice Hall, 2001.

MAGEE, John F. Logística industrial: análise e administração dos sistemas de suprimento e distribuição. São Paulo: Pioneira, 1977.

MARCONI, Marina de Andrade, LAKATOS, Eva Maria. Técnicas de pesquisa: planejamento e execução de pesquisas, amostragens e técnicas de pesquisa, elaboração, análise e interpretação de dados. 2.ed. São Paulo: Atlas, 1990.

MOSIMANN, Clara Pellegrinello, FISCH, Sílvio. Controladoria: seu papel na administração de empresas. 2. ed. São Paulo: Atlas, 1999.
NOVAES, Antônio Galvão. Logística e gerenciamento da cadeia de distribuição: estratégia, operação e avaliação. Rio de Janeiro: Campus, 2001.

OLIVEIRA, Luís Martins de. Controladoria: conceitos e aplicações. São Paulo: Futura, 1998.

PEREIRA, Maria José Lara de Bretas; FONSECA, João Gabriel Marques. Faces da decisão: as mudanças de paradigmas e o poder da decisão. São Paulo: Makron Books, 1997.

PORTER, Michael E. Vantagem competitiva: criando e sustentando um desempenho superior. 4.ed. Rio de Janeiro: Campus, 1992.

RICCIO, Edson Luiz. Conceitos de controladoria. São Paulo: FEA / USP, 1995.(mimeo)

RICHARDSON, Robert J. Pesquisa social: métodos e técnicas. São Paulo: Atlas, 1989.

RODRIGUES, Paulo Roberto Ambrosio. Introdução aos sistemas de transporte no Brasil e à logística internacional. São Paulo: Aduaneiras, 2000.

ROEHL-ANDERSON, Janice M., BRAGG, Steven M. The controller's function: the work of the managerial accountant. Nova York: John Wiley \& Sons, 1996.

SISTEMA FEDERAÇÃO DAS INDÚSTRIAS DO ESTADO DE SANTA CATARINA. Guia da Indústria de Santa Catarina 2000. Florianópolis: FIESC, maio/2000.

SLACK, Nigel et al. Administração da produção. São Paulo: Atlas, 1997. 